\title{
Perspectives in restoration: storage and pretreatments of seeds for better germination of Sudanian savanna-woodland species
}

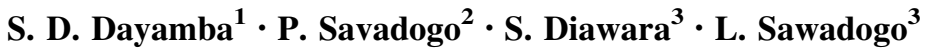

Received: 26 May 2014/Accepted: 25 October 2014/Published online: 30 March 2016

(C) Northeast Forestry University and Springer-Verlag Berlin Heidelberg 2016

\begin{abstract}
Insufficient knowledge of the germination ecology of local species is one of the main constraints to restoration of degraded rural lands. We tested seeds from fourteen Sudanian savanna species targeted for restoration for their response to two different pretreatments (conventional and prolonged acid pretreatments) and two different storage conditions (ambient room conditions and refrigerator at $4{ }^{\circ} \mathrm{C}$ ). For 6 of the studied species, longer soaking in sulphuric acid significantly improved germination rates and also reduced the germination time of some species. Storage condition, in general did not affect germination rates except for two species where cool storage depressed germination. The practical implication is that, for the species tested, when mature seeds are collected for plantation in
\end{abstract}

Project funding: This study is supported by Volkswagen Foundation (Grant Ref: 60420897, Dr Patrice Savadogo) and CGIAR

(Consultative Group on International Agricultural Research) Research Program on Dry lands (CRP 1.1). (Headquarters in Jordan).

The online version is available at http://www.springerlink.com

Corresponding editor: Zhu Hong

S. D. Dayamba

d.dayamba@cgiar.org; djibril.dayamba@yahoo.fr

1 World Agroforestry Centre (ICRAF), West and Central Africa Regional Office - Sahel Node, BP E5118 Bamako, Mali

2 World Agroforestry Centre \& International Crop Research Institute for the Semi-Arid Tropics (ICRAF-ICRISAT), West and Central Africa Region-Sahel Node, BP 12404 Niamey, Niger

3 Département Productions Forestières, Centre National de la Recherche Scientifique et Technologique, Institut de l'Environnement et de Recherches Agricoles, BP 10 Koudougou, Burkina Faso the upcoming rainy season, there is no need to invest in infrastructure and energy for storing in cold conditions. The study also revealed that in general when seeds are stored in ambient conditions from the time of collection up to seeding time, although germination rate does not increase, germination time is shortened and this could be of great interest in synchronizing germination in real field conditions.

Keywords Tropical dry forest - Seed storage conditions . Pretreatments · Regeneration · West Africa

\section{Introduction}

Restoration of degraded land remains a challenge for local, national and international organizations. Revegetation constitutes the most widely accepted and useful way to reduce erosion and protect soils against degradation during reclamation/restoration (Sheoran et al. 2010). Germination is the first critical phase of plant establishment and it can be delayed or hampered by various factors. First, blockage of germination or dormancy may be inherent to the seed itself and can be of many types namely, morphological, physiological, physical, and a combination of these types (Baskin and Baskin 1998). Each species in nature has its own germination behavior which includes, inter alia, the conditions required to break dormancy and to promote germination of non-dormant seeds (Liu et al. 2011). Some seeds may cycle through dormancy status.

For dormant seed, dormancy must be released before the seed can germinate and release of dormancy can be realized using pre-sowing treatments. In Burkina Faso, for most of the local tree species, the National Tree Seed Center has advised pre-sowing treatments and there have 
also been many studies of seed germination after different pretreatments (Zida et al. 2005; Dayamba et al. 2008, 2010). However, for some species subjected to conventional pre-treatments, germination still needs improvement (Dayamba et al. 2014). Moreover, in natural field conditions, most seeds of seasonal tropical forests, irrespective of dispersal time, remain dormant until the beginning of the rainy season, when they germinate (see Vieira et al. 2008). For large scale restoration (using rainfall), seed collection does not coincide with planting time and collected seeds must be stored for some time before planting. This poses challenges to maintaining seed viability because all seeds lose viability with age (Fenner and Thompson 2005) and storage conditions strongly affect seed germination (Alhamdan et al. 2011; Liu et al. 2011). However studies of storage issues are few or even nonexistent in the case of Sudanian savanna, especially in Burkina Faso. It is important to improve methods for seed handling between collections and sowing to raise the probability of producing vigorous seedlings and successful plantation establishment (Sanchez-Coronado et al. 2007). This is especially relevant because storage conditions that maximize seed viability are often species-specific (Pradhan and Badola 2012). Our study aimed to gather information that could contribute to filling the above identified gaps. We first compared two pre-sowing treatments in terms of seed germination for fourteen Sudanian savanna species and then, assessed how seed germination changed depending on storage conditions from the time of seed collection to planting time (beginning of rainy season) in the same year.

\section{Materials and methods}

\section{Seed sources}

We tested fourteen Sudanian savanna species, eight with physical dormancy and six without (Table 1). All species are important for provision of fuelwood, fodder and food, and all are prioritized for restoration. Seeds were all collected directly from the plants at the time of natural dispersal of each species in January-February 2013 in Laba $\left(11^{\circ} 40^{\prime} \mathrm{N}\right.$, $\left.02^{\circ} 50^{\prime} \mathrm{W}\right)$ and Tiogo $\left(12^{\circ} 13^{\prime} \mathrm{N}, 02^{\circ} 42^{\prime} \mathrm{W}\right)$ state forests in Burkina Faso, West Africa. All seeds were allowed to air-dry by keeping them in ambient room conditions (mean daily minimum and maximum temperatures were 16 and $32{ }^{\circ} \mathrm{C}$ respectively) until the time of the first germination trial (which started 3-4 weeks from date of collection). Seeds not used in the first trial were divided in two batches, one of which was stored in air-tight containers in a refrigerator (temperature $=4{ }^{\circ} \mathrm{C}$ ) and the other was kept in ambient conditions until the second germination trial.

\section{Seed treatments}

This study comprised two consecutive trials. The first trial aimed at identifying for each study species the pretreatment that increased germination rate. For this trial, each species was subjected to two pretreatments namely (1) the conventional treatment as advised by the National Tree Seed Center (CNSF) and (2) prolonged soaking in concentrated (95\%) sulphuric acid (Table 1). Seeds subjected to these two treatments were germinated for 30 days (methods described below). Based on the results of this trial, the best pretreatment was identified for each species. In a second trial, this best pretreatment was used on seeds that were stored in two different conditions namely (1) at ambient room conditions and (2) in a refrigerator $\left(\mathrm{T}=4{ }^{\circ} \mathrm{C}\right)$. For acid pretreatment, seeds of each species were soaked in sulphuric acid for the specified time (Table 1) and then thoroughly rinsed with tap water and soaked for $24 \mathrm{~h}$ in tap water before being transferred to Petri dishes on filter paper for germination tests.

\section{Germination test}

Seeds were placed in Petri dishes on two layers of filter paper moistened with tap water. A germination table was set to perform at $30{ }^{\circ} \mathrm{C}$ from 06:00 to $18: 00 \mathrm{~h}$ and $25^{\circ} \mathrm{C}$ from 18:00 to 06:00 h. The germination room was illuminated from 06:00 to 18:00 h with $20 \mu \mathrm{Em}^{-2} \mathrm{~s}^{-1}$ light from a fluorescent lamp (F40 W/33 RS cool white light) mounted on the germination table to simulate conditions of day and night. Four replications, each with 25 seeds, were used per species $\times$ treatment combination. The experiment was run for 30 days for all species. Germination was monitored on daily basis and seed showing a radicle of at least $2 \mathrm{~mm}$ long was considered as germinated and was recorded and discarded. Watering was done once or twice daily with tap water to avoid drying of the medium.

\section{Statistical analysis}

Germination rate $\left(G_{\mathrm{R}}\right)$ and mean germination time $\left(M_{\mathrm{GT}}\right)$ were calculated for each species and treatment as:

$G_{R}(\%)=\left(\frac{\sum n_{i}}{N}\right) \times 100$

$M_{G T}($ days $)=\frac{\sum\left(t_{i} \times n_{i}\right)}{N}$

where $n_{i}$ is the number of seeds germinated at each day, $N$ is total number of seeds sown and $t_{i}$ is the number of days starting from the date of sowing (Bewley and Black 1994). The calculated parameters were subjected to analysis of variance to test the effect of pre-treatments (1st 
Table 1 Conventional and prolonged concentrated sulphuric acid $(95 \%)$ pretreatments used for each study species

\begin{tabular}{|c|c|c|c|c|c|}
\hline Species & $\begin{array}{l}\text { Code } \\
\text { used }\end{array}$ & Family & $\begin{array}{l}\text { Dormancy } \\
\text { status }\end{array}$ & Conventional treatment & Prolonged acid soaking \\
\hline Acacia dudgeoni Craib. ex Holl. & Ac.dud & Leguminosae & ND & $\begin{array}{l}\text { Acid } 3 \mathrm{mn}+24 \mathrm{~h} \\
\text { water }\end{array}$ & $\begin{array}{l}\text { Acid } 30 \mathrm{mn}+24 \mathrm{~h} \\
\text { water }\end{array}$ \\
\hline Adansonia digitata $\mathrm{L}$. & Ad.dig & Bombacaceae & PD & $\begin{array}{l}\text { Acid } 60 \mathrm{mn}+24 \mathrm{~h} \\
\text { water }\end{array}$ & $\begin{array}{l}\text { Acid } 120 \mathrm{mn}+24 \mathrm{~h} \\
\text { water }\end{array}$ \\
\hline Albizia chevalieri Harms & Al.che & Leguminosae & PD & $\begin{array}{l}\text { Acid } 5 \mathrm{mn}+24 \mathrm{~h} \\
\text { water }\end{array}$ & $\begin{array}{l}\text { Acid } 60 \mathrm{mn}+24 \mathrm{~h} \\
\text { water }\end{array}$ \\
\hline Anogeissus leiocarpa Guill. \& Perr. & An.lei & Combretaceae & ND & $24 \mathrm{~h}$ in water & $\begin{array}{l}\text { Acid } 5 \mathrm{mn}+24 \mathrm{~h} \\
\text { water }\end{array}$ \\
\hline Balanites aegyptiaca (L.) Del. & Ba.aeg & Zygophyllaceae & ND & $72 \mathrm{~h}$ in water & $\begin{array}{l}\text { Acid } 120 \mathrm{mn}+24 \mathrm{~h} \\
\text { water }\end{array}$ \\
\hline Cassia sieberiana DC. & Ca.sie & Leguminosae & PD & $\begin{array}{l}\text { Acid } 5 \mathrm{mn}+24 \mathrm{~h} \\
\text { water }\end{array}$ & $\begin{array}{l}\text { Acid } 60 \mathrm{mn}+24 \mathrm{~h} \\
\text { water }\end{array}$ \\
\hline Combretum glutinosum Perr. ex DC & Co.glu & Combretaceae & ND & $24 \mathrm{~h}$ in water & $\begin{array}{l}\text { Acid } 10 \mathrm{mn}+24 \mathrm{~h} \\
\text { water }\end{array}$ \\
\hline Combretum micranthum G. Don & Co.mic & Combretaceae & ND & $24 \mathrm{~h}$ in water & $\begin{array}{l}\text { Acid } 10 \mathrm{mn}+24 \mathrm{~h} \\
\text { water }\end{array}$ \\
\hline Detarium microcarpum Guill. \& Perr. & De.mic & Leguminosae & ND & $\begin{array}{l}\text { Acid } 30 \mathrm{mn}+24 \mathrm{~h} \\
\text { water }\end{array}$ & $\begin{array}{l}\text { Acid } 120 \mathrm{mn}+24 \mathrm{~h} \\
\text { water }\end{array}$ \\
\hline Diospyros mespiliformis Hochst. ex A. DC. & Di.mes & Ebenaceae & PD & $\begin{array}{l}\text { Acid } 10 \mathrm{mn}+24 \mathrm{~h} \\
\text { water }\end{array}$ & $\begin{array}{l}\text { Acid } 120 \mathrm{mn}+24 \mathrm{~h} \\
\text { water }\end{array}$ \\
\hline Piliostigma reticulatum (DC.) Hochst. & Pi.ret & Leguminosae & PD & $\begin{array}{l}\text { Acid } 30 \mathrm{mn}+24 \mathrm{~h} \\
\text { water }\end{array}$ & $\begin{array}{l}\text { Acid } 120 \mathrm{mn}+24 \mathrm{~h} \\
\text { water }\end{array}$ \\
\hline $\begin{array}{l}\text { Piliostigma thonningii (Schumach.) Milne- } \\
\text { Redh. }\end{array}$ & Pi.tho & Leguminosae & PD & $\begin{array}{l}\text { Acid } 10 \mathrm{mn} *+24 \mathrm{~h} \\
\text { water }\end{array}$ & $\begin{array}{l}\text { Acid } 120 \mathrm{mn}+24 \mathrm{~h} \\
\text { water }\end{array}$ \\
\hline Tamarindus indica $\mathrm{L}$. & Ta.ind & Leguminosae & PD & $\begin{array}{l}\text { Acid } 10 \mathrm{mn}+24 \mathrm{~h} \\
\text { water }\end{array}$ & $\begin{array}{l}\text { Acid } 120 \mathrm{mn}+24 \mathrm{~h} \\
\text { water }\end{array}$ \\
\hline Terminalia avicennioides Guill. \& Perr. & Te.avi & Combretaceae & PD & $\begin{array}{l}\text { Acid } 30 \mathrm{mn}+24 \mathrm{~h} \\
\text { water }\end{array}$ & $\begin{array}{l}\text { Acid } 180 \mathrm{mn}+24 \mathrm{~h} \\
\text { water }\end{array}$ \\
\hline
\end{tabular}

* Conventional treatment is $5 \mathrm{mn}+24 \mathrm{~h}$ soaking in water. This was tested in previous paper (Dayamba et al. 2014, JTFS in press) and showed poor germination. This is why we increased the soaking time. Dormancy status: PD is physically dormant; ND is non dormant (Schelin et al. 2003; Razanamandranto et al. 2004, 2005; Zida et al. 2005; Dayamba et al. 2008; Jayasuriya et al. 2013). We also based on the prescriptions of the National Tree Seed Center (CNSF) and identified as non-dormant seeds that did not need scarification treatment to germinate

trial) and storage conditions (2nd trial). For seeds stored at ambient conditions and tested on the two occasions (trials 1 and 2), we analysed the effect of time elapsed between the two tests, on the germination of the species. Data set for germination rate was arcsine-transformed (Zar 1999) before analysis to improve homogeneity of variance and normality. The results were considered significant when $\mathrm{p}<0.05$ and to show tendency when $0.05<p<0.1$.

\section{Results}

For Acacia dudgeoni, Adansonia digitata, Albizia chevalieri, Cassia sieberiana, Combretum micranthum and Diopyros mespiliformis, longer soaking time in sulphuric acid significantly improved germination rate with improvement ranging from 11 to $65 \%$ (Fig. 1). For the latter 3 species, the germination time was also reduced by 3 to almost 9 days.

For Balanites aegyptiaca, Detarium microcarpum, Piliostigma reticulatum and Tamarindus indica, longer soaking in sulphuric acid depressed germination by 9-32\%. No significant effect was observed on the germination rate of Combretum glutinosum or Piliostigma thonningii but the germination time of the latter species was shortened by 11 days. Anogeissus leiocarpa and Terminalia avicennioides did not germinate irrespective of pretreatment.

The results of the second trial showed that for most of the tested species, storage condition did not significantly affect germination rate except for Adansonia digitata where cool storage for about 3 months depressed germination by $16 \%$ (Fig. 2), and Combretum glutinosum where refrigerator stored seeds did not germinate (5\% germination was recorded in ambient conditions). A. dudgeoni and 

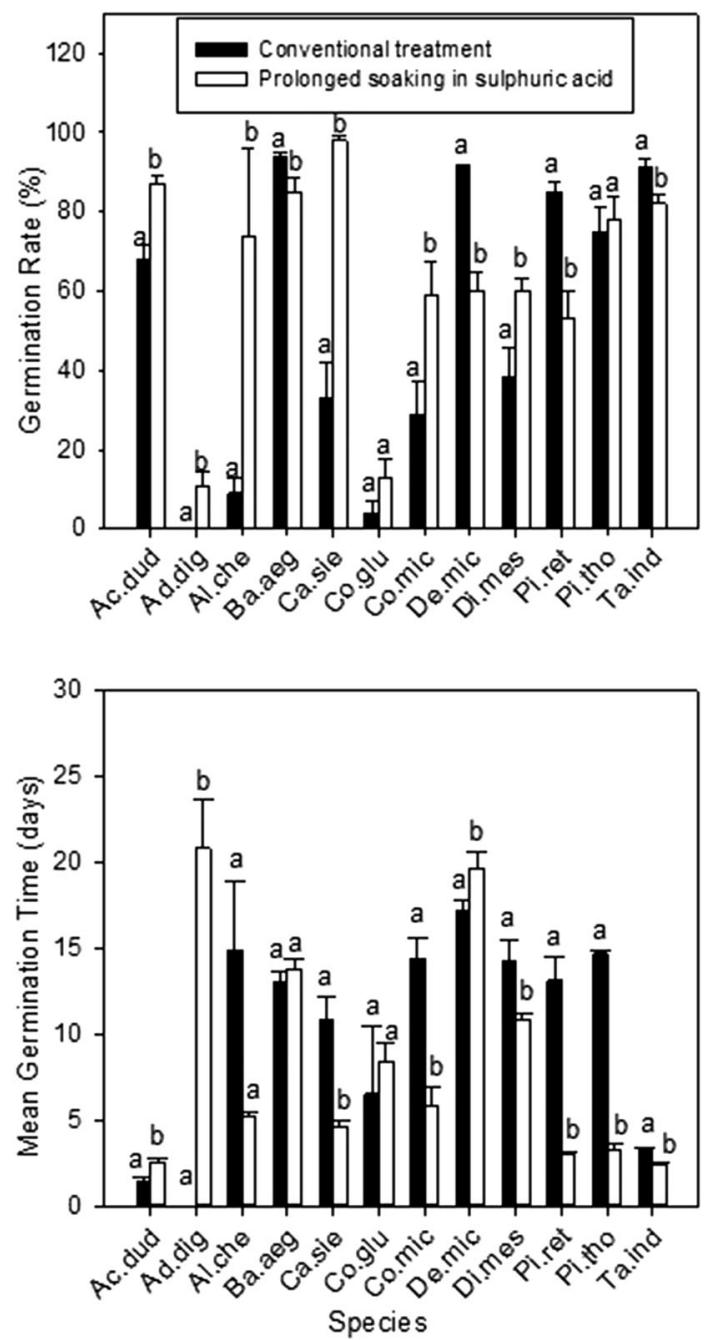

Fig. 1 Effect of different pretreatments on germination rate and mean germination time of Sudanian savanna species (Refer to Table 1 for the definition of conventional treatment and time for acid soaking for each species)

$D$. microcarpum stored in only one of either conditions were not included in this trial. A. leiocarpa, C. micranthum, and $T$. avicennioides showed low or nil germination irrespective of storage condition and were not included in this analysis. With respect to germination time, the 3 months of cool storage delayed germination by 1, 3 and 9 days for Albizia chevalieri, Diospyros mespiliformis and Piliostigma thonningii, respectively (Fig. 2).

When we compared germination of newly collected seeds to that of seeds stored in ambient conditions for 3 months, no significant difference was observed for any of the species except Combretum micranthum where germination was almost completely suppressed after 3 months of storage (59 vs. $1 \%$ ). For some species (A. dudgeoni, A. digitata, $D$. mespiliformis and $P$. reticulatum) with no effect on $G_{R}$, significant shortening of germination time (by
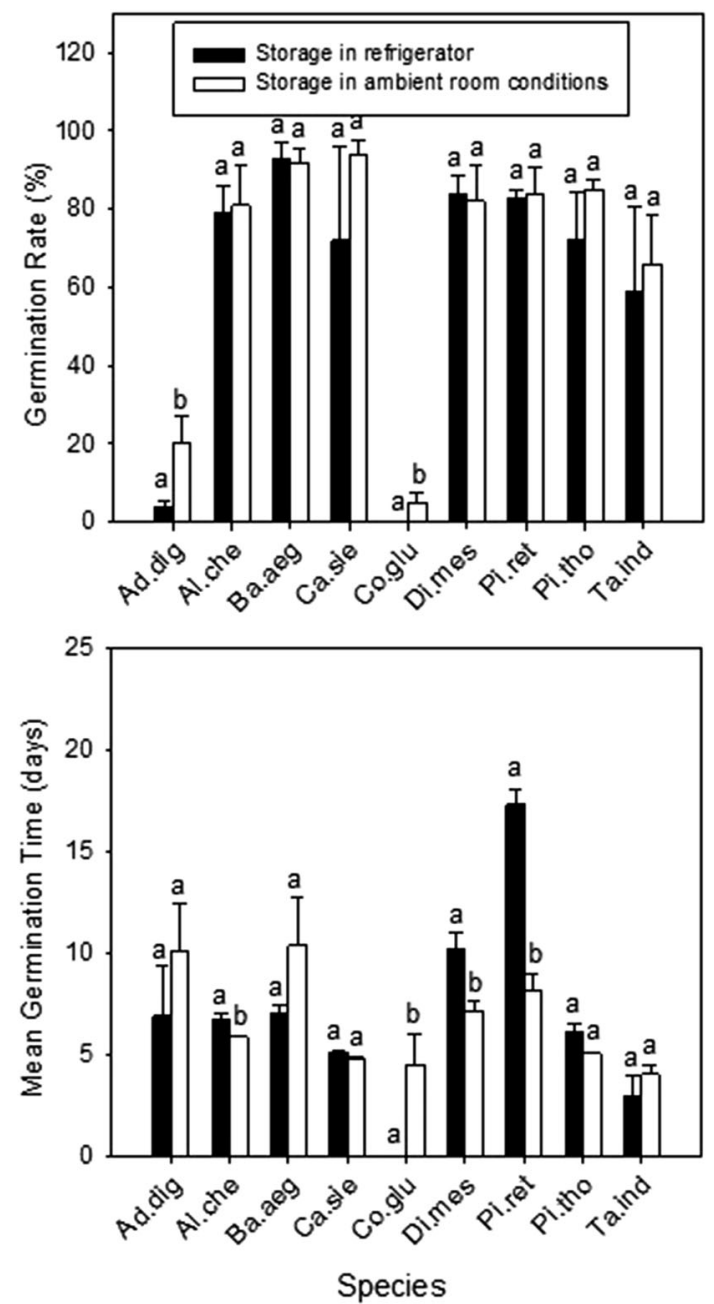

Fig. 2 Effect of storage conditions on germination rate and mean germination time of Sudanian savanna species

1-11 days) was observed (Fig. 3). For A. chevalieri and $P$. thonningii, although no effect was observed on $\mathrm{G}_{\mathrm{R}}$, the time spent in ambient conditions delayed the germination by 1 and 2 days respectively.

\section{Discussion}

In the present study, longer soaking in sulphuric acid improved germination rate of 6 of the tested species and shortened mean germination time for 6 others. The practical action of acid scarification is to disrupt the barrier for the uptake of water and oxygen by the seed and permit radicle emergence by weakening the seed coat structures (Baskin and Baskin 1998). Therefore if the duration of soaking is not adequate, scarification will not be complete and will not lead to expected germination. This is why determination of optimum time is of paramount interest (Baskin and Baskin 1998; Dayamba et al. 2014) especially 

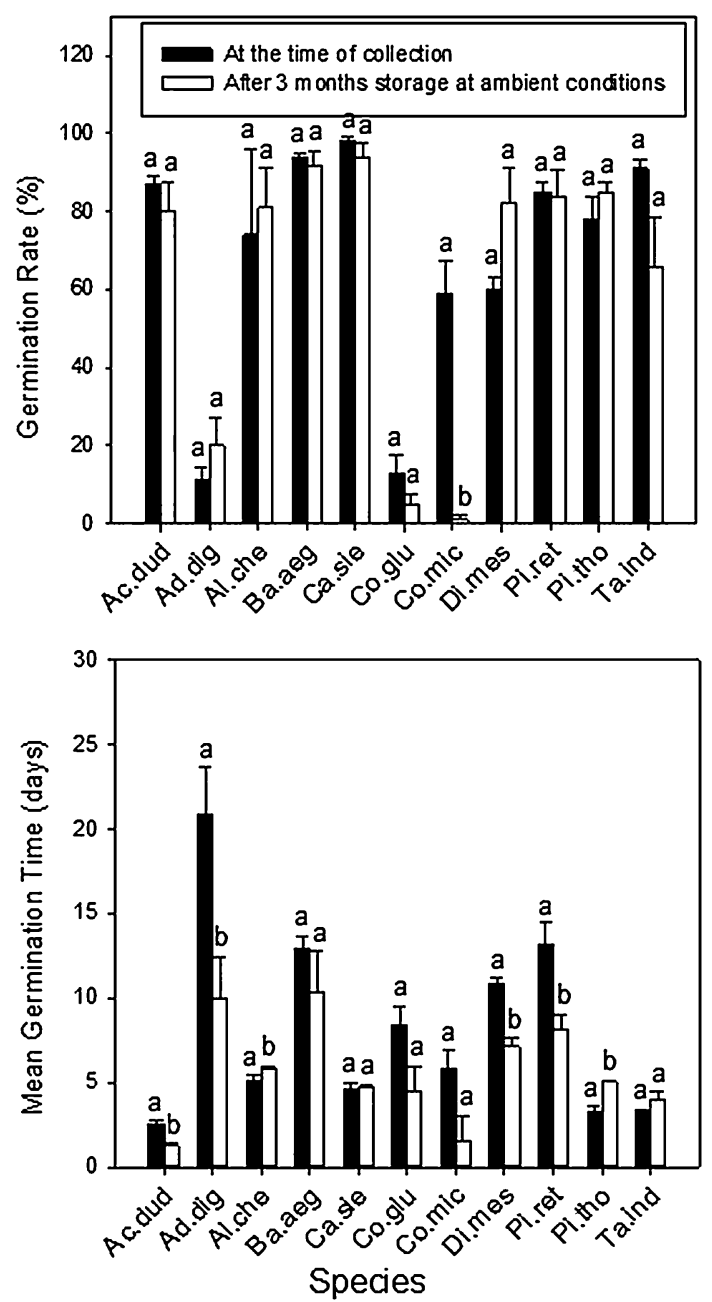

Fig. 3 Effect of seed storage time in ambient room conditions on germination rate of Sudanian savanna species

because excessively long soaking can lead to depressed germination as observed for 4 of our study species $(B$. aegyptiaca, D. microcarpum, $P$. reticulatum and $T$. indica), for which conventional pretreatments would be better. One species ( $P$. reticulatum) particularly drew our attention because in our previous study (Dayamba et al. 2014), no significant difference in $G_{R}$ was observed between the two soaking durations while the current study revealed that for this species, the $2 \mathrm{~h}$ soaking time was excessive and depressed germination. One of the reasons for the discrepancy of results between previous and current studies of this species could be that the current study used newly collected seeds with probably less thick coats compared to the 3 year old seeds used in previous study (seeds were collected in 2008 and tested in 2011 after storage in ambient conditions). Although this hypothesis would benefit from formal test, Baskin and Baskin (1998) already stated that the impermeability of coats develops as seeds dry. This draws attention to the fact that recommendations for seed pretreatments, apart from being species-specific, might need to consider seed age. Another species already tested by Dayamba et al. (2014) and of interest here is $P$. thonningii. Two hours of soaking significantly improved germination compared to $5 \mathrm{~min}$ but in the current study, germination rates were similar after soaking for $2 \mathrm{~h}$ and soaking for $10 \mathrm{~min}$. This suggests that soaking duration of $10 \mathrm{~min}$ is adequate. However, as in our previous study, the longer soaking gave substantially shorter $\mathrm{M}_{\mathrm{GT}}$ in the current study, which could be of great help in synchronizing germination to an earlier date in field rainfed restoration. This trial revealed that $C$. glutinosum showed very poor germination contrary to a study by Dayamba et al. (2008), and therefore requires further investigation (tests over longer storage periods and different conditions, different provenances) for a full understanding of its germination ecology.

For most of the tested species, conditions of storage in the present study did not show any significant difference in germination. Pradhan and Badola (2012) compared ambient room condition, refrigeration $\left(4^{\circ} \mathrm{C}\right)$ and $-15^{\circ} \mathrm{C}$, and observed that storage up to six months resulted in little variation in percent germination and differences were only observed after 12 months. The practical implication of this result is that, for the 9 species analyzed in this trial, when mature seeds are collected for plantation at the upcoming rainy season, there is no need to invest in infrastructure and energy for storing in cold conditions. This is especially relevant for species such as A. digitata and C. glutinosum, for which reduced germination was recorded after cool storage.

Combretum micranthum was the only species for which the germination rate at the time of seed collection was higher than after 3 months of storage at room conditions. One explanation for this would be that the species does not have primary dormancy (at the time of collection) but can evolve secondary dormancy after 3 months of storage in ambient room conditions. Storage at room conditions can also lead to seed deterioration (Mamo et al. 2011). In the present study, C. micranthum did not show a higher germination rate when stored in cool conditions; probably because the metabolic processes blocked in the seeds during cold storage needed more time in ambient conditions to resume. But this remains a hypothesis and a thorough and multi-parameter study would be required to better understand the germination ecology of this species.

All trials taken together, and assuming seed age is taken into consideration, we advise that A. dudgeoni, A. digitata, A. chevalieri, C. sieberiana, C. micranthum, D. mespiliformis and $P$. thonningii be pretreated following our suggested methods (prolonged acid soaking; Table 1). For $B$. aegyptiaca, D. microcarpum, $P$. reticulatum and T. indica conventional pretreatments would be better. A. leiocarpa 
and $T$. avicennioides failed to germinate under all pretreatments tested. The former species is known for its poor germination (Dayamba et al. 2008) partly due to production of empty dispersal units (Kambou and Guinko 1995) while the latter, although it produces viable embryos at the end of trials, has always showed low germination (Dayamba et al. 2014). Those two species and also $C$. glutinosum and $C$. micranthum require further investigations that consider in one experiment many variable parameters to allow better insight into their germination ecology.

\section{Conclusion}

This study aimed to assess the germination response of Sudanian savanna species to different pretreatments and storage conditions. Prolonged soaking in sulphuric acid had positive effects on $\mathrm{G}_{\mathrm{R}}$ and $\mathrm{M}_{\mathrm{GT}}$ of some of the species (compared to conventional treatments) while no effect was observed in other species and negative effects were recorded for a few others. Refrigerated storage from the time of seed collection to germination (which coincided with the beginning of the rainy season-suitable time for field planting) did not improve germination and even depressed it for two species. The practical implication of this is that, for the species tested, when mature seeds are collected for plantation at the upcoming rainy season, there is no need to invest in infrastructure and energy for storing in cold conditions. Also discrepancies were observed between current results and previous studies and were attributed to differences in seed age (pending confirmation by formal tests). Future studies should aim at assessing the additive and/or interactive effects of variable parameters (seed provenances, seed age, longer storage time-as commercial seeds are often stored for some years-and various pretreatments) to gain better insight into local species germination ecology.

\section{References}

Alhamdan AM, Alsadon AA, Khalil SO, Wahb-Allah MA, El Nagar M, Ibrahim AA (2011) Influence of storage conditions on seed quality and longevity of four vegetable crops. Am-Eurasian J Agric Environ Sci 11(3):353-359

Baskin CC, Baskin JM (1998) Seeds: ecology, biogeography, and evolution of dormancy and germination. Academic Press, San Diego, p 666

Bewley JD, Black M (1994) Seeds: physiology of development and germination, 2nd edn. Plenum Press, New York, p 445

Dayamba SD, Tigabu M, Sawadogo L, Oden PC (2008) Seed germination of herbaceous and woody species of the Sudanian savanna-woodland in response to heat shock and smoke. For Ecol Manag 256:462-470

Dayamba SD, Sawadogo L, Tigabu M, Savadogo P, Zida D, Tiveau D, Oden PC (2010) Effects of aqueous smoke solutions and heat on seed germination of herbaceous species of the Sudanian savanna-woodland in Burkina Faso. Flora 205:319-325

Dayamba SD, Santi S, Savadogo P (2014) Improving seed germination of four savanna-woodland species: effects of fire-related cues and prolonged soaking in sulphuric acid. J Trop For Sci 26(1):16-21

Fenner M, Thompson K (2005) The ecology of seeds. Cambridge University Press, UK, $250 \mathrm{pp}$

Jayasuriya KMGG, Wijetunga ASTB, Baskin JM, Baskin CC (2013) Seed dormancy and storage behavior in tropical Fabaceae: a study of 100 species from Sri Lanka. Seed Sci Res 23(04): 257-269

Kambou S, Guinko S (1995) La fleur et l'inflorescence de Anogeissus leiocarpus (DC.) Guill. et Perr. Acta Biol Benrodis 7:163-173

Liu K, Baskin JM, Baskin CC, Bu H, Liu M, Liu W, Du G (2011) Effect of storage conditions on germination of seeds of 489 species from high elevation grasslands of the eastern Tibet Plateau and some implications for climate change. Am J Bot 98(1):12-19

Mamo N, Nigusie D, Tigabu M, Teketay D, Fekadu M (2011) Longevity of Juniperus procera seed lots under different storage conditions: implications for ex situ conservation in seed banks. J For Res 22:453-459

Pradhan BK, Badola HK (2012) Effect of storage conditions and storage periods on seed germination in eleven populations of Swertia chirayita: a critically endangered medicinal herb in Himalaya. Sci World J. doi:10.1100/2012/128105

Razanamandranto S, Tigabu M, Neya S, Oden PC (2004) Effects of gut treatment on recovery and germinability of bovine and ovine ingested seeds of four woody species from the Sudanian savanna in West Africa. Flora 199:389-397

Razanamandranto S, Tigabu M, Sawadogo L, Oden PC (2005) Seed germination of eight savanna-woodland species from West Africa in response to different cold smoke treatments. Seed Sci Technol 33:315-328

Sanchez-Coronado ME, Coates R, Castro-Colina L, de Buen AG, Paez-Valencia J, Barradas VL, Huante P, Orozco-Segovia A (2007) Improving seed germination and seedling growth of Omphalea oleifera (Euphorbiaceae) for restoration projects in tropical rain forests. For Ecol Manag 243:144-155

Schelin M, Tigabu M, Eriksson I, Sawadogo L, Oden PC (2004) Predispersal seed predation in Acacia macrostachya, its impact on seed viability, and germination responses to scarification and dry heat treatments. New For 27:251-267

Sheoran V, Sheoran AS, Poonia P (2010) Soil reclamation of abandoned mine land by revegetation: a review. Int J Soil, Sediment Water, 3(2):1:20

Vieira DLM, de Lima VV, Sevilha AC, Scariot A (2008) Consequences of dry-season seed dispersal on seedling establishment of dry forest trees: should we store seeds until the rains? For Ecol Manag 256:471-481

Zar JH (1999) Biostatistical analysis, 4th edn. Prentice Hall Inc., Upper Saddle River, p 663

Zida D, Tigabu M, Sawadogo L, Oden PC (2005) Germination requirements of seeds of four woody species from the Sudanian savanna in Burkina Faso, West Africa. Seed Sci Technol 33:581-593 